\title{
$\underline{\mathbf{P}-147}$
}

\section{Biological Properties of Malaysian Tropical Seaweed for Topical Application}

\author{
Nurul Izza Nordin ${ }^{1}$, Badariah Abdullah ${ }^{1, *}$, Harmayumi Wahid ${ }^{1}$, Mazita Mohd Diah ${ }^{1}$, Siti \\ Kasmarizawaty Suboh ${ }^{1}$, Thavamanithevi Subramaniam ${ }^{1}$, Adibi Rahiman Md Nor ${ }^{2}$, Ropien Jokiman ${ }^{1}$ \\ and Zanariah Ujang ${ }^{1}$ \\ ${ }^{1}$ Industrial and Biotechnology Research Centre,SIRIM Berhad, 1, Persiaran Dato' Menteri, P.O Box 7035, 40911 Shah \\ Alam, Selangor Malaysia; ${ }^{2}$ Department of Fisheries Malaysia, Level 1-6, Lot 4G2, Wisma Tani, Precints 4, Federal \\ Government Administrative Centre,62628 Putrajaya,WP Putrajaya, Malaysia; E-mail: bdariah@sirim.my
}

The increasing demands on anti-oxidant and skin lightening agents in Asia Pacific market have created vast excitement in the cosmetic and pharmaceutical industry to introduce robust and effective, yet safe invention of topical product. The emergence of various herbal-based products stimulates comprehensive study to evaluate the potential of various tropical plants. Seaweed is a marine tropical alga that has been claimed to possess good anti-aging and anti-pigmentation activity. Nonetheless, these claims are not supported by strong scientific evidences. Three species of Malaysian tropical seaweed, Turbinaria sp. (TR), Gracilaria sp. (G) and Padina sp. (PD) were studied for anti-oxidant and skin lightening properties. Crude aqueous extracts of the selected seaweed species (TRA, GA and PDA) were evaluated using ABTS and mushroom tyrosinase assay, for anti-oxidant and skin lightening activity, respectively. Amongst the extracts, TRA showed the most potent anti-oxidant activity. This extract displayed lower $\mathrm{IC}_{50}$ value of $0.063 \pm 0.001 \mathrm{mg} / \mathrm{ml}$, whilst commercial anti-oxidant agent, vitamin C (L-ascorbic acid) demonstrated better $\mathrm{IC}_{50}$ value at $0.008 \mathrm{mg} / \mathrm{ml}$. In addition, TRA showed good skin lightening activity at $2 \mathrm{mg} / \mathrm{ml}$ with $50.11 \pm$ $0.04 \%$ inhibition against tyrosinase enzyme activity. Therefore, this study could underpin the dual inhibitory effect of the selected seaweed species as anti-oxidant and skin lightening agent for topical application. The cellular antioxidant activity (CAA) for quantifying the antioxidant activities will then further evaluate to measure the antioxidant potential of seaweed extracts. The cell based bioassay represents a promising analytical tool for potential biological activity.

Keywords: Anti-oxidant, skin lightening, seaweed. 